\title{
Glassidium brokenosis
}

EDITOR'S

CHOICE

- Additional material is available. To view please visit the journal (http://dx.doi.org/ 10.1136/bcr-2014-208178)

Department of Acute Medicine, National Health Service, Lister Hospital, Stevenage, UK

\section{Correspondence to} Dr John Jungpa Park, john.park3@nhs.net

Accepted 6 December 2014

CrossMark

o cite: Park JJ. BMJ Case Rep Published online:

[please include Day Month Year] doi:10.1136/bcr-2014208178

\section{John Jungpa Park}

\section{DESCRIPTION}

A 24-year-old junior doctor was unable to see after breaking his glasses at a very busy acute medical unit at a district general hospital. This resulted in significant deterioration in his optical function and affected daily junior doctor tasks such as coffee making, writing discharge scripts and taking bloods. Notably, he was unable to recognise his patients or his colleagues unless standing close up to them causing awkward communication and social situations. Also, his consultant had complained that his morning coffee had tasted suspiciously like hot chocolate, although this was impossible to confirm biochemically.

The doctor was seen at the estates department at the hospital, who delightedly assessed the doctor and his glasses. They were able to make a diagnosis of glassidium brokenosis and undertook an emergency repair using the most up-to-date 'fivemethod' guidelines. ${ }^{1}$ The doctor was discharged with his glasses fixed, and recommended to return for a follow-up with chocolates.

The doctor has returned into his ward community with his glasses intact and is now able to perform his daily duties (figures 1 and 2).

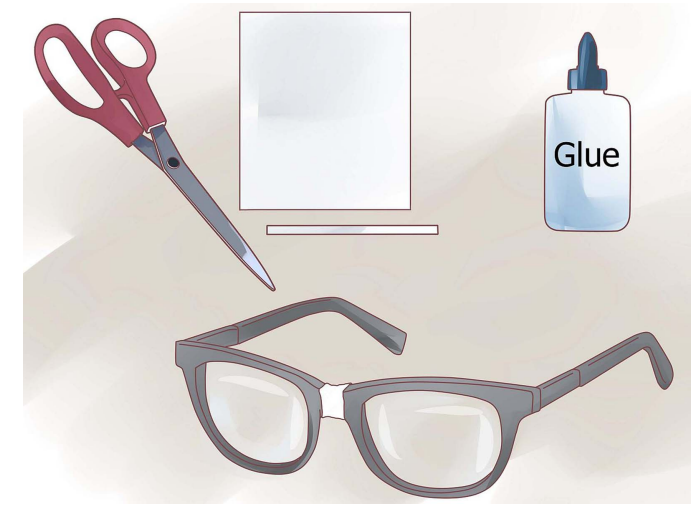

Figure 1 Glassidium brokenosis (used with permission from ref 1).

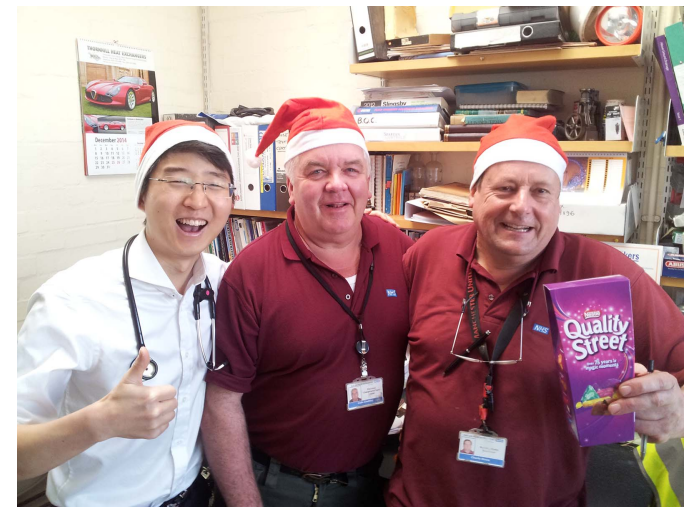

Figure 2 At follow up clinic.

\section{Learning points}

- Unexpected events happen within the hospital wards which can disrupt clinical activities.

- The estates department form a part of the multidisciplinary team, as do the cleaners, porters and catering staff.

- Working together can help to solve unexpected problems. In this case, fixing a junior doctor's broken glasses ensured he could provide safe patient care.

Acknowledgements To Peter, who fixed my glasses first and was admitted to hospital. We wish you a speedy recovery.

Competing interests None.

Patient consent Obtained.

Provenance and peer review Not commissioned; externally peer reviewed.

\section{REFERENCE}

1 Wikihow. How to Repair Eyeglasses. http://www.wikihow.com/ Repair-Eyeglasses (accessed 15 Nov 2014)

Copyright 2014 BMJ Publishing Group. All rights reserved. For permission to reuse any of this content visit http://group.bmi.com/group/rights-licensing/permissions.

BMJ Case Report Fellows may re-use this article for personal use and teaching without any further permission.

Become a Fellow of BMJ Case Reports today and you can:

- Submit as many cases as you like

- Enjoy fast sympathetic peer review and rapid publication of accepted articles

- Access all the published articles

- Re-use any of the published material for personal use and teaching without further permission

For information on Institutional Fellowships contact consortiasales@bmjgroup.com

Visit casereports.bmj.com for more articles like this and to become a Fellow 